\title{
PENENTUAN KADAR FENOLIK TOTAL EKSTRAK ETANOL DAUN NILAM (Pogostemon cablin Benth.) DENGAN METODE SPEKTROFOTOMETRI UV-VIS
}

\author{
Masdiana Tahir, A.Muflihunna, Syafrianti \\ Fakultas Farmasi, Universitas Muslim Indonesia \\ 1masdiana.tahir@umi.ac.id
}

\begin{abstract}
One of the plants that is well known in the community and is used as a traditional medicine is patchouli (Pogostemon cablin Benth.). It contains essential oils, flavonoids, saponins, tannins, glycosides, terpenoids and steroids. The alcohol content, such as patchouli alcohol and its derivatives, phenol, and a group of terpenoids in patchouli oil has antibacterial activity. The aim at this research to determine the total phenolic condition the ethanol extract from the patchouli leaves. The extract obtained was analyzed ist content using UV-Vis spectrophotometer. The measurements were done at the maximum wavelength of 662,85 $\mathrm{nm}$. The result showed that the total phenolic in patchouli leave is $327,84 \mathrm{mgGAE} / \mathrm{gram}$ of extract.
\end{abstract}

Keywords: Phenol, Patchouli Leaves (Pogostemon cablin Benth.), UV-Vis Spectrophotometry

\section{PENDAHULUAN}

Salah satu tanaman yang sudah dikenal dalam masyarakat dan digunakan sebagai obat tradisional adalah nilam (Pogostemon cablin Benth.) (Wijayakusuma dkk, 1992). Nilam (Pogostemon cablin Benth.) merupakan tanaman yang sudah banyak dikenal oleh masyarakat luas Tanaman nilam banyak ditanam untuk diambil minyaknya. Minyak nilam banyak dibutuhkan untuk industri kosmetik, parfum, antiseptik, dan lain-lain (Mangun, 2009).

Daun nilam (Pogostemon cablin Benth.) memiliki kandungan minyak atsiri, flavonoid, saponin, tanin, glikosida, terpenoid dan steroid. Kandungan alkohol seperti patchouli alcohol beserta turunannya, fenol dan golongan terpenoid pada minyak nilam memiliki aktivitas antibakteri (Mangun, 2009).

Senyawa fenolik di alam terdapat sangat luas mempunyai variasi struktur yang luas, mudah ditemukan di semua tanaman, daun, bunga dan buah. Ribuan senyawa fenolik di alam telah diketahui strukturnya antara lain flavonoid, fenol monosiklik sederhana, fenil propanoid, polifenol (lignin, melanin, tanin), dan kuinon fenolik (Fauziah, 2008).

Tanaman nilam telah banyak dimanfaatkan sebagai obat tradisional. Akar dari tanaman ini digunakan untuk pencahar, bagian daun sebagai deodoran, obat luka, wasir, disentri, penyakit empedu, gangguan haid dan obat peluruh haid. Semua bagian dari tumbuhan ini juga dapat dimanfaatkan sebagai obat sakit kepala, dan obat diare (Halimah, 2010). Minyak nilam juga bermanfaat dalam pembuatan obat antiradang, antifungi, antiserangga, afrodisiak, antiinflamasi, antidepresi dan dekongestan (Mangun, 2009).
Secara umum senyawa fenol memiliki sifat bakteriosid, antimetik, antihelmintik, antiasmatik, analgetik, antiinflamasi, meningkatkan mortilitas usus, antimikroba, dan masih banyak lagi (Andarwulan, 2012).

Berdasarkan hal tersebut diatas maka dilakukan penelitian penentuan kadar fenolik total yang terkandung pada daun nilam (Pogostemon cablin Benth.) dengan metode spektrofotometri UV-Vis.

\section{METODE PENELITIAN}

\section{A. Alat dan Bahan}

Alat yang digunakan pada penelitian ini adalah alat-alat gelas (pyrex) dan spektrofotometer UV-Vis tipe evolution 201.

Bahan-bahan yang digunakan adalah aquabidestillata, asam galat p.a, besi (III) klorida $\left(\mathrm{FeCl}_{3}\right)$, ekstrak etanol daun nilam (Pogostemon cablin Benth.), etanol p.a, etanol $96 \%$, natrium karbonat $\left(\mathrm{Na}_{2} \mathrm{CO}_{3}\right.$ p.a), dan reagen Folin-Ciocalteau.

\section{B. Pengambilan dan Pengolahan Sampel}

Pengambilan sampel daun nilam

(Pogostemon cablin Benth.) dilakukan pada pagi hari sekitar pukul 10.00 WITA di desa Lawewe Kabupaten Palopo, dengan cara mengambil daun yang masih segar secara manual. Kemudian dibersihkan dari kotoran-kotoran yang menempel dengan menggunakan air yang mengalir dan dikeringkan dengan cara diangin-anginkan tanpa sinar matahari \pm 1 minggu. Setelah kering sampel dipotong-potong kecil dan diserbukkan menggunakan blender. 


\section{Ekstraksi daun nilam (Pogostemon cablin Benth.)}

Sebanyak 300 gram serbuk daun nilam (Pogostemon cablin Benth.) dimasukkan kedalam wadah maserasi, ditambahkan pelarut etanol $96 \%$ hingga serbuk simplisia terendam, dibiarkan selama 3-4 hari. Setelah proses ekstraksi pertama selesai, ampasnya dimaserasi kembali dengan cairan penyari yang baru. Ekstrak kental yang telah dikumpulkan lalu diuapkan dengan menggunakan alat Rotary Vacuum Evaporator hingga diperoleh ekstrak etanol kering (Ahmad dkk, 2015).

\section{Analisis Kualitatif Kandungan Fenolik}

Senyawa golongan fenolik dapat dideteksi dengan menggunakan $\mathrm{FeCl}_{3} 1 \%$. Pengujiannya yaitu sebanyak 1 gram sampel dilarutkan dengan menggunakan pelarut etanol $96 \%$ sebanyak $2 \mathrm{ml}$. Larutan yang dihasilkan diambil sebanyak $1 \mathrm{ml}$ kemudian ditambahkan 2 tetes larutan $\mathrm{FeCl}_{3}$. Terbentuknya warna hijau, merah, ungu, biru, atau hitam yang kuat menunjukkan adanya senyawa fenolik dalam sampel (Harbone, 1987).

\section{E. Analisis Kuantitatif}

1. Penentuan panjang gelombang maksimal ( $\lambda$ maks) Penentuan panjang gelombang maksimal asam galat dilakukan dengan mengukur larutan asam galat konsentrasi $5 \mathrm{ppm}$ pada range panjang gelombang 400-800 $\mathrm{nm}$ dengan menggunakan spektrofotometer UV-Vis dan diperoleh panjang gelombang maksimal yaitu $662,85 \mathrm{~nm}$.

\section{Pengukuran Larutan Standar Asam Galat}

Dibuat konsentrasi 3, 13, 23, 33, 43, dan 53 ppm yang dipipet dari larutan standar asam galat konsentrasi 100 ppm, kemudian ditambahkan 0,4 ml reagen Folin Ciocalteau, dikocok dan dibiarkan 4-8 menit. Ditambahkan 4,0 ml larutan $\mathrm{Na}_{2} \mathrm{CO}_{3}$, dikocok hingga homogen. Kemudian dicukupkan dengan aquabidestillata hingga $10 \mathrm{ml}$ dan didiamkan selama 2 jam pada suhu ruangan. Diukur absorbansi pada panjang gelombang maksimal $662,85 \mathrm{~nm}$, dibuat kurva kalibrasi hubungan antara konsentrasi asam galat $(\mu \mathrm{g} / \mathrm{ml})$ dengan absorbansi (Ahmad dkk., 2015).

3. Penentuan kadar fenolik total ekstrak etanol daun nilam (Pogostemon cablin Benth.)

Penentuan kadar fenolik total pada ekstrak etanol daun nilam (Pogostemon cablin Benth.) merujuk pada prosedur Chun dkk., (2003) yaitu dibuat dengan cara menimbang $10 \mathrm{mg}$ ekstrak etanol daun nilam kemudian dilarutkan dengan $10 \mathrm{ml}$ etanol p.a dan dihomogenkan. Dipipet $1 \mathrm{ml}$ dari larutan tersebut, kemudian ditambahkan dengan $0,4 \mathrm{ml}$ reagen Folin Ciocalteau dikocok dan dibiarkan 4-8 menit, tambahkan 4,0 ml larutan $\mathrm{Na}_{2} \mathrm{CO}_{3}$ kocok hingga homogen. Dicukupkan dengan aquabidestillata hingga $10 \mathrm{ml}$ dan diamkan selama 2 jam pada suhu ruangan.

\section{HASIL DAN PEMBAHASAN}

Hasil ekstraksi daun nilam (Pogostemon cablin Benth.) diperoleh sebesar 25,5312 gram dari bobot serbuk kering sebanyak 300 gram. Sedangkan persen rendamen dari ekstrak etanol daun nilam (Pogostemon cablin Benth.) sebesar 8,5104\%. Penentuan rendamen berfungsi untuk mengetahui kadar metabolit sekunder yang terbawa oleh pelarut tersebut, namun tidak dapat menentukan jenis senyawa yang terbawa (Ukieyanna, 2012).

Uji kualitatif dilakukan untuk mengetahui komponen kimia pada tumbuhan, untuk senyawa fenolik digunakan $\mathrm{FeCl}_{3}$ dan reagen Folin Ciocalteau. Hasil pengujian memberikan reaksi positif yang membuktikan adanya kandungan senyawa fenolik dalam ekstrak etanol daun nilam (Pogostemon cablin Benth.).

Tabel 1. Hasil ekstraksi rosella merah (Hibiscus sabdariffa L.)

\begin{tabular}{cccc}
\hline Sampel & Pereaksi & Warna & Ket. \\
\hline $\begin{array}{c}\text { Ekstrak etanol } \\
\text { daun nilam }\end{array}$ & $\mathrm{FeCl}_{3}$ & Hijau tua & $(+)$ \\
$\begin{array}{c}\text { Ekstrak etanol } \\
\text { daun nilam }\end{array}$ & $\begin{array}{c}\text { Folin } \\
\text { Ciocalteau }\end{array}$ & Kuning & $(+)$ \\
\hline
\end{tabular}

Keterangan: (+) mengandung senyawa fenolik

Untuk uji kuantitatif dilakukan penentuan kadar fenolik total pada ekstrak etanol daun nilam (Pogostemon cablin Benth.) yang merujuk pada prosedur Chun dkk., (2003) menggunakan metode Folin Ciocalteau. Metode ini merupakan metode yang paling umum digunakan untuk menentukan kandungan fenolik total dalam tanaman dengan pertimbangan bahwa dengan teknik ini pengerjaannya lebih sederhana dan reagen Folin Ciocalteau digunakan karena senyawa fenolik dapat bereaksi dengan Folin membentuk larutan yang dapat diukur absorbansinya.

Sebagai larutan standar atau pembanding digunakan asam galat yang merupakan salah satu fenolik alami dan stabil. Menurut Viranda (2009) asam galat termasuk dalam senyawa fenolik turunan asam hidroksibenzoat yang tergolong asam fenolik sederhana. Asam galat direaksikan dengan reagen Folin Ciocalteau menghasilkan warna kuning yang menandakan bahwa mengandung fenolik, setelah itu ditambahkan dengan larutan $\mathrm{Na}_{2} \mathrm{CO}_{3}$ sebagai pemberi suasana basa. Selama reaksi berlangsung, gugus hidroksil pada senyawa fenolik bereaksi dengan 
pereaksi Folin Ciocalteau, membentuk kompleks molibdenum-tungsten berwarna biru dengan struktur yang belum diketahui dan dapat dideteksi dengan spektrofotometer. Warna biru yang terbetuk akan semakin pekat, setara dengan konsentrasi ion fenolak yang terbentuk, artinya semakin besar konsentrasi senyawa fenolik maka semakin banyak ion fenolak yang akan mereduksi asam heteropoli (fosfomolibdatfosfotungstat) menjadi kompleks molibdenumtungsten sehingga warna yang dihasilkan semakin pekat.

Untuk menentukan kadar fenolik totalnya, terlebih dahulu dilakukan running panjang gelombang larutan standar asam galat dari range 400$800 \mathrm{~nm}$ menggunakan spektrofotometri UV-Vis. Panjang gelombang maksimal yang diperoleh yaitu $662,85 \mathrm{~nm}$. Selanjutnya dilakukan pengukuran absorbansi larutan standar asam galat dari beberapa konsentrasi yang diukur pada panjang gelombang maksimal yang diperoleh.

Hasil pengukuran absorbansi larutan standar asam galat dibuat kurva kalibrasi hubungan antara konsentrasi (C) dengan absorbansi (A) dan diperoleh persamaan garis linear. Adapun syarat kelayakan untuk metode analisis yang diterima untuk koefisien korelasi (r) dari range 0,996-1 yang nantinya digunakan untuk penentuan kadar fenolik total ekstrak etanol daun nilam (Pogostemon cablin Benth.). Berdasarkan hal tersebut diperoleh persamaan regresi linear yaitu $\mathrm{y}=0,005 \mathrm{x}+0,312$ dengan koefisien korelasi (r) 0,996 yang memenuhi syarat kelayanan metode analisis, yang dapat ditunjukkan pada Gambar 1.

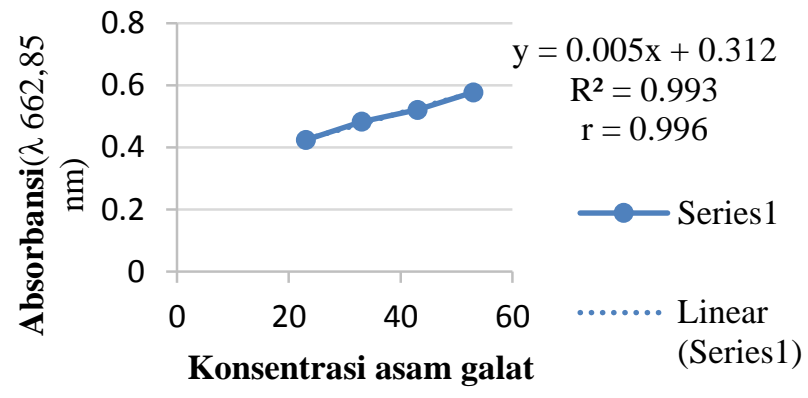

Gambar 1. Kurva kalibrasi asam galat pada panjang gelombang $662,85 \mathrm{~nm}$

Tabel 2. Hasil penentuan kadar fenolik pada ekstrak etanol daun nilam (Pogostemon cablin Benth.)

\begin{tabular}{ccccc}
\hline Replikasi & $\begin{array}{c}\text { Absorbansi } \\
(\mathbf{Y})\end{array}$ & $\begin{array}{c}\text { Kandungan } \\
\text { Fenolik Awal } \\
(\mathbf{m g} / \mathbf{L})\end{array}$ & $\begin{array}{c}\text { Kandungan Fenol } \\
(\mathbf{m g ~ G A E} / \mathbf{g} \text { ekstrak) }\end{array}$ & $\begin{array}{c}\text { Rata-rata Kandungan } \\
\text { Fenolik (mg GAE/g } \\
\text { ekstrak) }\end{array}$ \\
\hline R1 & 0,456 & 28,8 & 287,43 & \\
R2 & 0,406 & 18,8 & 187,62 & 327,84 \\
R3 & 0,567 & 51 & 508,47 & \\
\hline
\end{tabular}

Pada pengukuran senyawa fenolik total dibuat sebanyak tiga replikasi untuk keperluan akurasi data. Berdasarkan hasil penelitian ini diperoleh kadar fenolik total ekstrak etanol daun nilam (Pogostemon cablin Benth.) sebesar 327,84mgGAE/ gram ekstrak, artinya dalam setiap gram ekstrak etanol daun nilam (Pogostemon cablin Benth.) terdapat fenolik yang setara dengan $327,84 \mathrm{mg}$ asam galat. Senyawa fenolik yang terkandung dalam ekstrak etanol daun nilam (Pogostemon cablin Benth.) merupakan hasil metabolit sekunder yang potensial sebagai sumber bahan baku obat yang berperan sebagai antioksidan.

\section{KESIMPULAN}

Berdasarkan hasil penelitian yang telah dilakukan maka dapat disimpulkan bahwa kadar fenolik total ekstrak etanol daun nilam (Pogostemon cablin Benth.) sebesar 327,84 mgGAE/gram ekstrak.

\section{DAFTAR PUSTAKA}

Ahmad, A.R., Juwita., Ratulangi, S.A.D., dan Malik, A., 2015, Pharm Sci Res, Penetapan Kadar Fenolik dan Flavanoid Total Ekstrak Metanol Buah dan daun Patikala (Etlingera elatior (Jack) R.M.SM), 2 (1) : 1-10.

Andarwulan, N., dan Faradilla., Fitri, R.H., 2012, Senyawa Fenolik pada Buah Manggis Dari Indonesia, Penerbit SEAFAST IPB, Bogor Jawa Barat.

Chun, O.K., Kim, D.O., dan Lee, C, Y., 2003,J Agric Food Chem,Superoxide Radical Scavenging Activity of The Major Polyohenols in Fresh Plums.

Fauziah, L., 2008, Studi Dimerisasi Asam, FMIPA, Universita Indonesia, Depok.

Halimah, P.P.D., dan Zetra, Y., 2010, Minyak Atsiri Dari Tanaman Nilam (Pogostemon cablin Benth.) Melalui Metode Fermentasi Dan Hidrodistilasi Serta Uji Bioaktivitasnya, Kimia FMIPA - ITS. 
Harborne, J.B., 1987, Metode Fitokimia: Penuntun Cara Modern Menganalisa Tumbuhan, Terbitan Kedua, Terjemahan Kosasih Padmawinata dan Iwang Soediro, Bandung, ITB.

Mangun, H. M. S., 2009, Nilam, Penebar Swadaya, Jakarta.

Ukieyana, E., 2012, Aktivitas Antioksidan, Kadar Fenolik Dan Flavanoid Total Tumbuhan Suruhan (Peperomia pellucid L. Kunth). Fakultas Teknologi Pertanian Institut Pertanian Bogor. Bogor.

Viranda P.M, 2009, Pengujian kandungan Senyawa yang terdapat dalam Tomat, Jurnal P. Universitas Indonesia.

Wijayakusuma, K.M.H., Dalimanta S., Yaputra T., dan Wibawa B., 1992, Tanaman Berkhasiat Obat Indonesia. Jilid I., Pustaka Kartini, Jakarta: 1-5. 